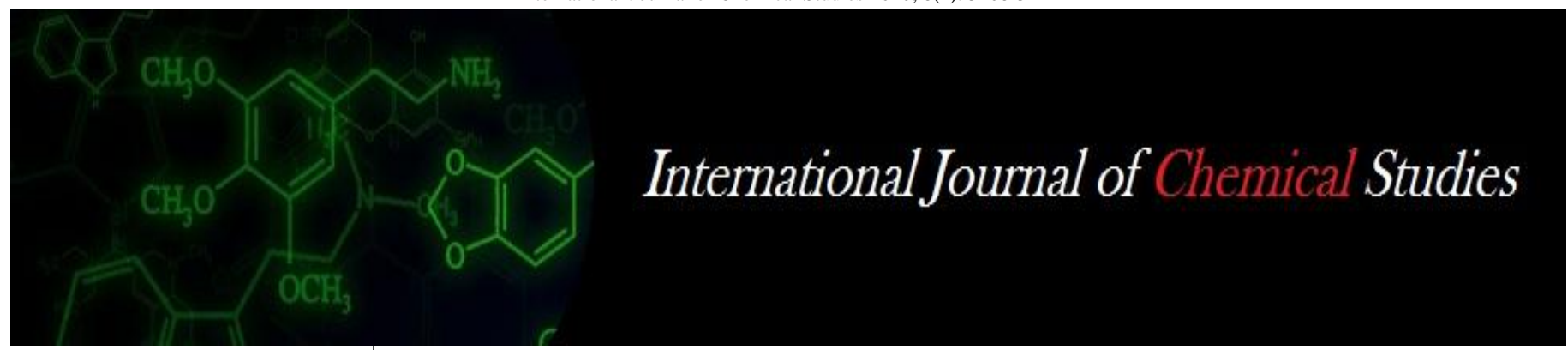

P-ISSN: 2349-8528

E-ISSN: 2321-4902

www.chemijournal.com

IJCS 2020; 8(4): 3108-3111

(C) 2020 IJCS

Received: 10-05-2020

Accepted: 12-06-2020

\section{SK Swain}

Department of Farm Machinery

and Power, College of Agricultural

Engineering \& Technology, Odisha

University of Agriculture and

Technology, Odisha, India

\section{AK Dash}

Krishi Vigyan Kendra, Gajapati,

Gajapati, Odisha, India

\section{AK Mohapatra}

Department of Farm Machinery and Power, College of Agricultural

Engineering \& Technology, Odisha

University of Agriculture and

Technology, Odisha, India

\section{DM Das}

Department of Farm Machinery and Power, College of Agricultural Engineering \& Technology, Odish University of Agriculture and Technology, Odisha, India

\section{Behera}

Department of Farm Machinery and Power, College of Agricultural Engineering \& Technology, Odisha

University of Agriculture and

Technology, Odisha, India

BR Nayak

Regional Research \& Technology Transfer Sub Station, Moto, Bhadrak, Gajapati, Odisha, India

\section{Mohapatra}

Department of Farm Machinery and Power, College of Agricultural Engineering \& Technology, Odisha University of Agriculture and Technology, Odisha, India
Corresponding Author:

SK Swain

Department of Farm Machinery and Power, College of Agricultural Engineering \& Technology, Odisha University of Agriculture and

Technology, Odisha, India

\section{A study on mechanization of rice-green gram cropping system using animal power on small farms in Odisha following conservation farming with cost-economics}

\author{
SK Swain, DM Das, AK Dash, AK Mohapatra, D Behera, BR Nayak and \\ M Mohapatra
}

DOI: https://doi.org/10.22271/chemi.2020.v8.i4al.10127

\begin{abstract}
A field experiment was conducted in farmers' fields in village-Govindpur, Mohana, Gajapati district, Odisha where rice-green gram cropping system is the prevailing practice. For conservation agriculture point of view, performance evaluation of the CIAE bullock drawn 3 row seed drill under zero till condition was conducted for line sowing of green gram during Rabi season following kharif paddy and it was compared with conventional method of twice ploughing by local wooden plough followed by manual broadcasting of green gram seeds. Performance evaluation of OUAT bullock drawn mb plough, OUAT bullock drawn puddler and OUAT bullock drawn 8 row drum seeder was conducted for line sowing of pre-germinated paddy seeds during kharif season which was compared with conventional random transplanting method for wet land paddy cultivation. The overall performance CIAE seed drill with zero till tynes was superior to the conventional method considering the higher yield and $\mathrm{B}: \mathrm{C}$ ratio and lesser labour requirement along with plant growth parameters.Considering the plant growth parameters and yield parameters and cost of operation the bullock drawn drum seeder was found superior to conventional random transplanting method.
\end{abstract}

Keywords: mechanization, rice-green gram cropping, animal power on small farms, conservation farming with cost-economics

\section{Introduction}

Rice - green gram cropping sequence is the dominant crop production system followed in the state of Odisha. Paddy is the major cereal crop of Odisha with the area, production and yield as 42.26 lakh ha, 68.28 lakh MT and 16.16 q/ha respectively (Economic Survey 2011-12, Odisha). Paddy is grown under wet land condition primarily during kharif season and under irrigated conditions in rabi season where conventional manual random transplanting is followed. The high yielding rice varieties have been growing in transplanted condition since their introduction, with a belief that transplanted rice usually produces $10-15 \%$ more yield than

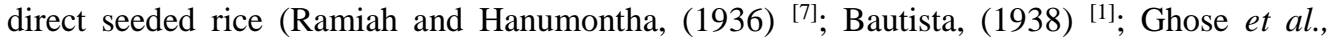
(1960) ${ }^{[3]}$; IRRI, (1971) $\left.{ }^{[4]}\right)$. Some recent studies reveal that there is no yield difference between direct seeding and transplanting practices of rice production when weed control and other intercultural operations are done properly. Subbaiah et al., (2000) ${ }^{[10]}$ cited the advantages of direct wet seeding of rice in comparison to transplanting as faster and easier crop establishment, reduced labour use, lesser drudgery, earlier crop maturity (8-10 days), more efficient water use due to reduced crop duration and increased benefit-crop ratio. They further opined that direct wet seeding has every potential to occupy the place of transplanted rice in command areas of Karnataka, Andhra Pradesh,' Tamil Nadu and Uttar Pradesh especially under rain fed low land rice ecosystem. Chavan et al., (2012) ${ }^{[2]}$ evaluated 8 row manual operated drum seeder in the Konkan region for seeding in both kharif and rabi season with proper irrigation practices. During field test the theoretical field capacity was calculated as $0.2 \mathrm{ha} / \mathrm{h}$, while effective field capacity was observed to be $0.11 \mathrm{ha} / \mathrm{h}$. The field efficiency of the seeder was found to be 55 per cent. The cost of operation of drum seeder is $\square 32.73 /$ - per hour and $\square$ 297/- per hectare. Singh et al., (2012) ${ }^{[8]}$ conducted an OFR on manual drum 
seeder for seeding paddy (Oryza sativa) versus conventional method of transplanting of paddy to afford a technology for farmers. The results of the study showed that the cost of operation for sowing paddy using drum seeder was 800 Indian rupee (INR) per ha as compared to INR 30000 per ha in conventional method. Grain yield was $60 \mathrm{Q} / \mathrm{ha}$ for drum seeded paddy and $58 \mathrm{Q} /$ ha for transplanted paddy which was not showing a wide difference. The benefit cost $(\mathrm{B}: \mathrm{C})$ ratio of drum seeding was calculated as 4.59 as compared to 3.89 in case of transplanting method. They further emphasized that the dry seeder technology is preferred because of low draft requirement, labour saving, natural resource conservation, better output/profits and less occupational health hazards. Islam, M. S. et al. (2010) ${ }^{[5]}$ developed a BRRI modified drum type row seeder incorporating few changes in IRRI manual drum type seeder for line sowing of pre-germinated paddy seeds and conducted field experiments to compare its performance with hand broadcasted paddy system. It was reported that the BRRI modified drum type row seeder, with a seeding rate of $60 \mathrm{~kg} / \mathrm{ha}$, performed better for an optimum crop yield. Suitable and automated mechanization exists in India as compared to Southeast Asian countries because of several factors, specifically three major drivers: the pull factor of labour shortages in rural areas, the push factor from government subsidies, and the pull factor of creating awareness through educating youth and farmers (Knowledge faber, 2013) ${ }^{[6]}$. The number and types of farm implements vary among villages depending upon crops grown, rainfall, soil type, and agricultural ecosystem (Srinivasarao et al. 2013) ${ }^{[9]}$.

Of late, the concept of conservation agriculture has been introduced in the state to maintain soil health. Conservation tillage is any method of soil cultivation that leaves the previous year's crop residue (such as corn stalks or wheat stubble) on fields before and after planting the next crop, to reduce soil erosion and runoff. In modern agriculture, mechanization of soil tillage, allowing higher working depths and speeds and the use of certain implements like ploughs, disk harrows and rotary cultivators have been remarkably increased; but with due course of time, these practices have shown detrimental effects on soil structure. Excessive tillage of agricultural soils may result in short term increases in fertility, but will degrade soils in the medium term. Structural degradation, loss of organic matter, erosion and falling biodiversity are all to be expected. Incidentally, the animal energy for agriculture is often regarded as renewable energy/ green energy or clean energy has got a key role since the small and marginal farmers who dominate the Indian as well as state agrarian sector survive with bullock farming system. At present, more than $84 \%$ farmers of the state of Odisha come under small and marginal farmers' category who cultivates around $43 \%$ of the total cultivable land. In ricepulse cropping system, the conservation agricultural practices using bullock power need to be assessed properly for the benefit of majority of farmers. The present experiment is proposed to study the scope of farm mechanization of wet land rice and rice-based cropping system using animal power on small farms following conservation farming with costeconomics. The performance of the different resource conservation technologies with respect to functional parameters of bullock drawn CIAE 3 row Seed drill, OUAT bullock drawn 8 row drum seeder in rice-green gram cropping system were compared. The performance of different methods of green gram establishment with respect to conservation agriculture considering plant growth parameters, yield parameters, soil parameters and economics of use were studied. Further, the performance of different methods of paddy establishment with respect to conservation agriculture considering plant growth parameters, yield parameters and economics of use were also compared.

\section{Materials and Methods}

The field experiment was conducted with 5 farmers in Govindpur village, Mohana, Gajapati district, where ricegreen gram cropping system is the prevailing practice. For conservation agriculture point of view, performance evaluation of the CIAE bullock drawn 3 row seed drill under zero till condition was conducted for line sowing of green gram during Rabi season following kharif paddy and it was compared with conventional method of twice ploughing by local wooden plough followed by manual broadcasting of green gram seeds. Performance evaluation of OUAT bullock drawn mb plough, OUAT bullock drawn puddler and OUAT bullock drawn 8 row drum seeder was conducted for line sowing of pre-germinated paddy seeds during kharif season which was compared with conventional random transplanting method for wet land paddy cultivation. This field experiment was conducted following two capacity building programmes on operation, use and maintenance of bullock drawn improved implements for paddy and green gram crop in the said village in collaboration with the KVK, Gajapati and NGO "SACAL". For green gram and paddy, high yielding variety seed PDM-54 and Swarna were selected. Recommended package of practices with references to fertilizer and plant protection measure were followed for the experiment. The functional parameters, plant growth parameters and yield parameters were recorded to compare the performance of both the methods of establishment of green gram and paddy.

Nos of farmers $\quad: 5$

Area, acres $\quad: 3.0$

Crop \& variety : Green gram, variety- PDM 54

Paddy, variety- Swarna

Year \& Season

Location

\section{: 2019, Rabi \& 2019, Kharif}

Village- Govindpur, Block-

Mohana, Dist.- Gajapati Average

Size of plot : $60 \mathrm{~m} \mathrm{x} 40 \mathrm{~m}$

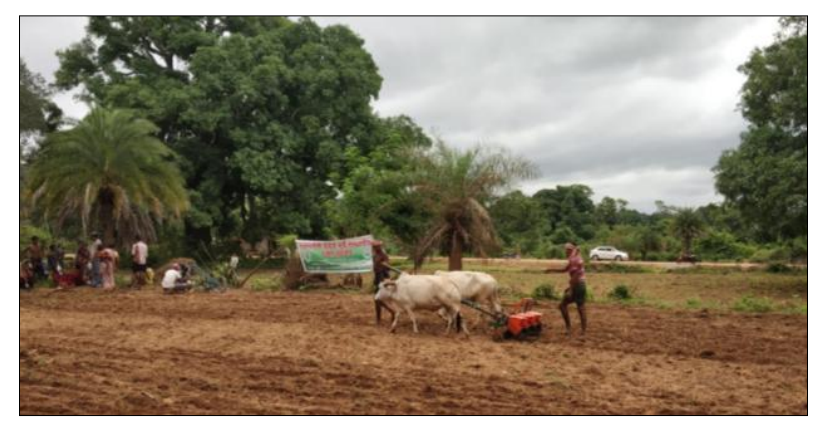

Fig 1: Demonstration of Bullock drawn CIAE 3 row seed drill for line sowing green gram seeds in farmers' field in Mohana, Gajapati 

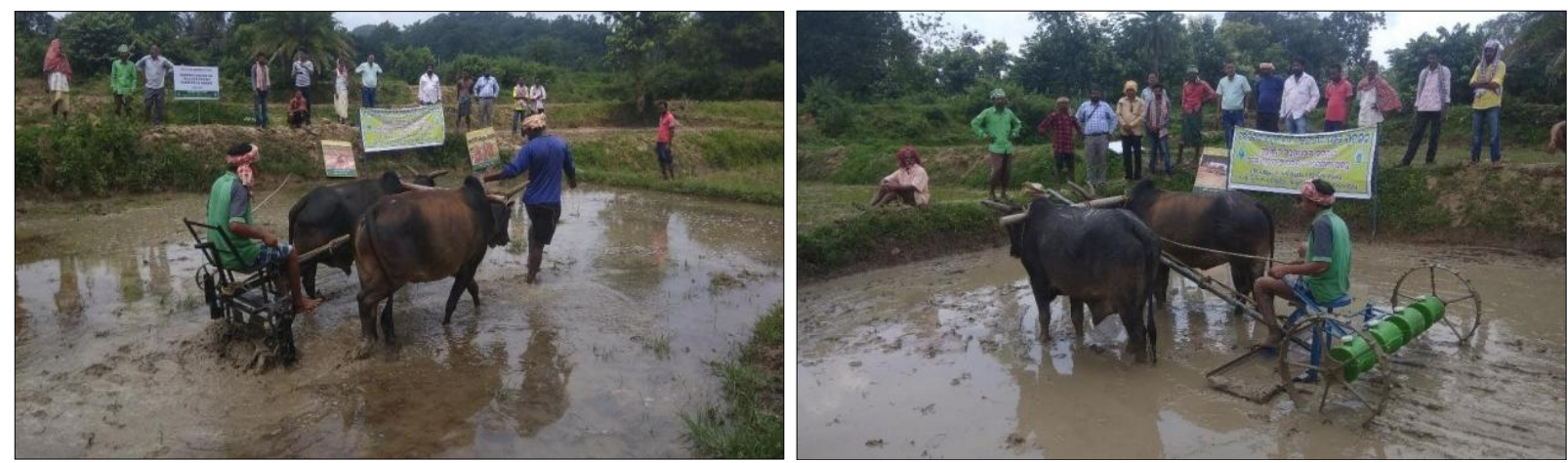

Fig 2: Demonstration of OUAT Puddler and OUAT Drum seeder in farmers' field in Mohana, Gajapati

\section{Results and Discussion}

Theresults on functional parameters of different methods of green gram establishment under resource conservation technologies, conducted during rabi-2019 indicated that the average actual field capacity of the CIAE bullock drawn 3 row seed drill was $0.13 \mathrm{ha} / \mathrm{h}$ with $64.50 \%$ field efficiency and average seed rate was $22.50 \mathrm{~kg} / \mathrm{ha}$. The average power requirement was found to be $0.34 \mathrm{hp}$ with average speed of operation of $2.2 \mathrm{kmph}$ and average draft of $404.2 \mathrm{~N}$. The cost of operation was found to be $\square 982.00$ per ha as compared to $\square 3800.00$ per ha in case of conventional method of twice ploughing by bullock drawn mb plough followed by manual broadcasting. The average grain yield and $\mathrm{B}: \mathrm{C}$ ratio were found to be $7.5 \mathrm{q} / \mathrm{ha}$ and 1.82 in conventional method as compared to $7.75 \mathrm{q} / \mathrm{ha}$ and 2.25 respectively with the CIAE three row seed drill. The overall performance CIAE seed drill with zero till tynes was superior to the conventional method considering the higher yield and $\mathrm{B}: \mathrm{C}$ ratio and lesser labour requirement along with plant growth parameters.

Table 1: Results on functional parameters of different methods of green gram establishment under resource conservation technologies (Rabi, 2019)

\begin{tabular}{|c|c|c|c|c|c|c|c|c|}
\hline Treatment details & $\begin{array}{c}\text { Actual field } \\
\text { capacity, ha/h } \\
\mathbf{h} / \mathbf{h a}\end{array}$ & $\begin{array}{c}\text { Speed of } \\
\text { operation, } \mathbf{k m p h}\end{array}$ & $\begin{array}{c}\text { Draft, } \\
\mathbf{N}\end{array}$ & $\begin{array}{c}\text { Power, } \\
\text { hp }\end{array}$ & $\begin{array}{c}\text { Cost of } \\
\text { operation, } \\
\square / \mathbf{h a}\end{array}$ & $\begin{array}{c}\text { Seed } \\
\text { rate, } \\
\mathbf{k g} / \mathbf{h a}\end{array}$ & $\begin{array}{c}\text { Labour } \\
\text { requirement, } \\
\text { man days/ha }\end{array}$ & $\begin{array}{c}\text { Field } \\
\text { efficiency, } \\
\text { percent }\end{array}$ \\
\hline $\begin{array}{c}\text { Line sowing by CIAE BD 3 row seed } \\
\text { drill-Zero till }\end{array}$ & $\begin{array}{c}0.13 \\
7.69\end{array}$ & 2.2 & 404.2 & 0.34 & 982 & 22.50 & 1.82 & 64.50 \\
\hline $\begin{array}{c}\text { Twice ploughing and Manual } \\
\text { broadcasting }\end{array}$ & $\begin{array}{c}0.03 \\
35.7\end{array}$ & - & - & - & 3800 & 35.00 & 5.95 & - \\
\hline
\end{tabular}

Table 2: Results on plant growth and yield parameters of different methods of green gram establishment under resource conservation technologies $($ Rabi, 2019)

\begin{tabular}{|c|c|c|c|c|c|c|c|c|c|}
\hline Treatment details & $\begin{array}{c}\text { No of } \\
\text { branches }\end{array}$ & $\begin{array}{c}\text { Plant } \\
\text { height, } \\
\text { cm }\end{array}$ & $\begin{array}{c}\text { No of plants/ } \\
\text { sq } \mathrm{m}\end{array}$ & $\begin{array}{c}\text { No of pods/ } \\
\text { plant }\end{array}$ & $\begin{array}{c}\text { No of } \\
\text { seeds/ pod }\end{array}$ & $\begin{array}{l}1000 \text { grain } \\
\text { weight, } g\end{array}$ & $\begin{array}{c}\text { Grain yield, } \\
\text { q/ha }\end{array}$ & $\begin{array}{c}\text { Stover yield } \\
\text { q/ha }\end{array}$ & $\begin{array}{l}\mathrm{B}: \mathrm{C} \\
\text { ratio }\end{array}$ \\
\hline $\begin{array}{c}\text { CIAE BD } 3 \text { row seed drill- } \\
\text { Zerotill }\end{array}$ & 4.4 & 24.80 & 39.8 & 32.0 & 5.50 & 26.9 & 7.75 & 11.3 & 2.25 \\
\hline $\begin{array}{l}\text { Conventional Manual } \\
\text { broadcasting Method }\end{array}$ & 3.7 & 25.2 & 48.8 & 31.4 & 5.70 & 27.3 & 7.50 & 10.5 & 1.82 \\
\hline
\end{tabular}

Table 3: Results on functional parameters of different methods of paddy establishment under resource conservation technologies (Kharif, 2019)

\begin{tabular}{|c|c|c|c|c|c|c|c|c|}
\hline Treatment details & $\begin{array}{c}\text { Actual field } \\
\text { capacity, ha/h } \\
\mathbf{h} / \mathbf{h a}\end{array}$ & $\begin{array}{c}\text { Speed of } \\
\text { operation, } \\
\mathbf{k m p h}\end{array}$ & $\begin{array}{c}\text { Draft, } \\
\mathbf{N}\end{array}$ & $\begin{array}{c}\text { Power, } \\
\mathbf{h p}\end{array}$ & $\begin{array}{c}\text { Cost of } \\
\text { operation, } \\
\square / \mathbf{h a}\end{array}$ & $\begin{array}{c}\text { Seed } \\
\text { rate, } \\
\mathbf{k g} / \mathbf{h a}\end{array}$ & $\begin{array}{c}\text { Labour } \\
\text { requirement, } \\
\text { man days/ha }\end{array}$ & $\begin{array}{c}\text { Field } \\
\text { efficiency, } \\
\text { percent }\end{array}$ \\
\hline $\begin{array}{c}\text { OUAT Bullock drawn 8 row } \\
\text { drum seeder }\end{array}$ & $\begin{array}{c}0.16 \\
6.25\end{array}$ & 1.71 & 445.37 & 0.29 & $2378 /-$ & 31.4 & 6.00 \\
\hline $\begin{array}{c}\text { T8:Control-Manual random } \\
\text { transplanting }\end{array}$ & - & - & - & - & 16900 & 41.52 & 52.00 \\
\hline
\end{tabular}

- Cost of conventional transplanting: $\square$ 16900/- per ha [(30 workers/ha for transplanting +20 workers for nursery uprooting \& transporting + bullock with plough man 1 day with 2 workers for nursery bed preparation)
- Cost of planting by 8-row bullock drawn drum seeder: $\square$ $1478 /$ - per ha [(operating cost of drum seeder is $\square$ $136.42 / \mathrm{h}) \times 6.25 \mathrm{hrs} / \mathrm{ha})+1$ worker for watching 3 days] 
Table 4: Results on plant growth and yield parameters of different methods of paddy establishment under resource conservation technologies (Kharif, 2019)

\begin{tabular}{|c|c|c|c|c|c|c|c|c|}
\hline Treatment details & $\begin{array}{l}\text { No of plants/sqm at } \\
\text { maximumtillering }\end{array}$ & \begin{tabular}{|c|}
$\begin{array}{c}\text { Plant height, } \\
\text { cm }\end{array}$ \\
\end{tabular} & $\begin{array}{c}\text { No of } \\
\text { panicles/sq m }\end{array}$ & $\begin{array}{c}\text { No of grains/ } \\
\text { panicle }\end{array}$ & $\begin{array}{c}1000 \text { grain } \\
\text { weight, } g\end{array}$ & \begin{tabular}{|c|} 
Grain \\
yield, $\mathrm{q} / \mathrm{ha}$
\end{tabular} & \begin{tabular}{|c|} 
Straw \\
yield, $\mathrm{q} / \mathrm{ha}$
\end{tabular} & $\begin{array}{l}\mathrm{B}: \mathrm{C} \\
\text { ratio }\end{array}$ \\
\hline $\begin{array}{l}\text { OUAT Bullock drawn } 8 \\
\text { row drum seeder }\end{array}$ & 385 & 122.4 & 351 & 121 & 24.6 & 50.4 & 62.8 & 1.84 \\
\hline $\begin{array}{l}\text { Control-Manual random } \\
\text { transplanting }\end{array}$ & 348 & 110.8 & 328 & 115 & 22.3 & 52.5 & 63.7 & 1.48 \\
\hline
\end{tabular}

The results on functional parameters of different methods of paddy establishment under resource conservation technologies, conducted during kharif-2019 season indicated that the average actual field capacity of the bullock drawn drum seeder was $0.16 \mathrm{ha} / \mathrm{h}$ with $58.4 \%$ field efficiency and average seed requirement of $31.4 \mathrm{~kg} / \mathrm{h}$. The average power requirement was found to be $0.29 \mathrm{hp}$ with average speed of operation of $1.17 \mathrm{kmph}$ and average draft of $445.4 \mathrm{~N}$. The average cost of operation and $\mathrm{B}: \mathrm{C}$ ratio were found out to be $\square 2378.00$ per ha and 1.84 as compared to $\square 16,900.00$ per ha and 1.48 respectively for conventional method of manual random transplanting. The labour requirement for conventional method was 52 man days per ha as compared to 6.0man days per ha. These results are in agreement with the results cited by Chavan et al., (2012) [2] and Singh et al., (2012) ${ }^{[8]}$. Although there are a number of limitations in the bullock drawn drum seeder method like controlled condition of field, protection of pre-germinated paddy seeds from birds up to 3 days after sowing and unwarranted weather conditions; but this method is superior to the conventional method considering the higher labour requirement, shortage of labour during peak hours, higher drudgery and most importantly higher cost involvement. Considering the plant growth parameters and yield parameters and cost of operation the bullock drawn drum seeder is superior to conventional random transplanting method.

\section{Conclusion}

Mechanization of wet land rice through use of bullock drawn 8 row drum seeder during kharif season followed by use of bullock drawn 3 row zero till drill (CIAE design) for line sowing of green gram during rabi season in rice based cropping system using animal power on small farms are found to be suitable considering the cost- economics while conservation farming is also followed. The small and marginal farmers of Odisha who depend on animal power for agricultural operations need to use these improved bullockdrawn implements to reduce their cost of operation, labour requirement and drudgery involvement. While the Rice-green gram cropping system dominates the agricultural scenario in the state, conservation agricultural practices using these improved implements should further be promoted for sustainable agriculture.

\section{References}

1. Bautista BR. Palagad rice culture in the Philippines, Philippine Journal of Agriculture. 1938; 2:381-391.

2. Chavan SP, Palkar SM. Performance evaluation of paddy drum seeder. International Journal of Agricultural Engineering. 2010; 3(2):279-287.

3. Ghose RLM, Chatge MB, Subrahmanyan V. Rice in India. Indian Conference of Agricultural Research, New Delhi, 1960, 1-470.

4. IRRI. Annual Report. International Rice Research Institute (IRRI), Los Banos, Philippines, 1971.
5. Islam MS, Ahmad D. Crop Establishment Technologies for Lowland Rice Cultivation in Bangladesh: Hand Seeding vs. Machine Seeding. Pertanika J Sci. \& Technol. 2010; 18(1):95-103.

6. Knowledgefaber. Agricultural Mechanization India. Report, 2013.

7. Ramiah K, Hanumantha K. Broadcasting vs transplanting. Tropical Agriculture. 1936; 26(5):310-313.

8. Singh S, Hensel O. On Farm Research (OFR) on Transplanting Paddy: A "Best-Bet" Prototype for Drudgery Reduction. International Journal of Agriculture Research and Review. 2012; 2(4):483-490.

9. Srinivasarao Ch, Dixit S, Srinivas I, Sanjeeva Reedy B, Adake RV, Borkar S. Operationalization of Custom Hiring Centres on Farm Implements in Hundred Villages in India. Central Research Institute for Dryland Agriculture, Hyderabad, Andhra Pradesh, 2013, 1-151.

10. Subbaiah SV, Balasubramanian V. Wet Seeding of Rice in India. DRR. Hyderabad, 2000, 1-58. 